\title{
LEGAL AND INSTITUTIONAL FRAMEWORK FOR PROMOTING OIL PIPELINE SECURITY IN NIGERIA
}

\author{
Amalachukwu Okafor* \\ Ayobami Olaniyan**
}

\begin{abstract}
Oil pipelines are no ordinary assets, and their security is of utmost importance especially in a country like Nigeria where oil pipelines are the major means of transporting crude oil. Nigeria relies on this means of transportation, which has been the victim of various physical attacks over the years by vandals and militant groups. This has affected the transportation of crude oil, which isthe most important resource sustaining the Nigerian economy, putting it in jeopardy. This article appraises the efficacy of relevant Nigerian legislation providing for oil pipelines security; highlights the weaknesses of the current regulatory arrangement, and suggests legal reforms to make oil transportation through pipelines efficient, effective and secure in Nigeria. These reforms include the need to have a comprehensive legislation on oil pipeline security; the need to review relevant legislation providing for the security of oil pipelines in Nigeria; proper funding of the security agencies saddled with the overall responsibility for managing as well as safeguarding the pipelines to ensure their productivity; and overhauling the entire security apparatus put in place to protect oil pipelines in Nigeria by having a sustainable and strategic approach to dealing with oil pipeline insecurity.
\end{abstract}

Keywords: Pipelines, Oil, Vandalism, Sabotage, Security.

DOI: https://dx.doi.org/10.4314/jsdlp.v8i2.10

\section{INTRODUCTION}

The importance of oil pipelines in an economy that is heavily dependent on crude oil, like Nigeria, cannot be overemphasized. Nigeria is the largest oil producer in Africa and fourth biggest exporter of liquefied

* Lecturer, Department of Public and International Law, College of Law, Afe Babalola University, Ado-Ekiti, Nigeria

** Lecturer, Department of Public and International Law, College of Law, Afe Babalola University, Ado-Ekiti, Nigeria. 
natural gas (LNG) in 2015. ${ }^{1}$ Oil pipelines are the major means of transporting crude oil in many countries, Nigeria inclusive; hence they are important to Nigerian oil production. ${ }^{2}$ The pipelines generally distribute the fuel needed for daily activities acrossNigeria. Therefore, they are valuable tothe physical and economic output of the nation. ${ }^{3}$ Together with the products they carry, pipelines help to provide economic growth to the various communities across the country where they are laid by providing jobs around their maintenance and service. ${ }^{4}$ Some of the advantages of transporting oil through pipelines include safety, stability, lower cost, and higher efficiency. Observably, where this mode of transportation is disrupted, it is bound to cause a major setback to the surrounding communities and to the nation at large,given the reliance on this infrastructure.

The security of oil pipelines then becomes an important issue in this context. Oil is without question, one of the main pillars on which Nigeria's economy currently stands. Crude oil being the major source of Nigeria's national income, as well as a key product for the export market, it needs to be properly protected and managed. Over the years, there have been recurrent issues over pipeline vandalism in different parts of the country, especially in the Niger Delta region, translating into financial losses sometimes running into several billions of dollars. ${ }^{5}$ According to the Nigerian National Petroleum Corporation (NNPC), 700,000 barrels of crude oil per day (bpd) were lost in 2016 to pipeline sabotage. ${ }^{6}$

1 US Energy Information Administration, “Country Analysis Brief: Nigeria” (EIA, 6 May 2016) < https://www.eia.gov/beta/international/analysis_includes/ countries_long/Nigeria/nigeria.pdf $>$ accessed 31 August 2017.

2 Consumer Energy Alliance, "The Importance of Pipeline Infrastructure" (16 May 2017). <https://consumerenergyalliance.org/2017/05/importancepipeline-infrastructure/ $>$ accessed 31 August 2017.

3 Ibid.

4 Ibid.

5 E. Ejoh and P. Okafor "Nigeria loses $\$ 100 \mathrm{~b}$ revenue to pipelines sabotageKachikwu" Vanguard Newspapers(15 February 2017)<https:// www.vanguardngr.com/2017/02/nigeria-loses-100b-revenue-pipelinessabotage-kachikwu/> accessed 1 October 2017.

6 See Premium Times "How pipeline vandalism reduced Nigeria's oil production by 40\% - NNPC", Premium Times (14 September 2017) <https:// www.premiumtimesng.com/news/headlines/243204-pipeline-vandalismreduced-nigerias-oil-production-40-nnpc.html > accessed 1 October 2017. In 2017 alone, NNPC has recorded 27 breaching incidents on the Trans Niger Pipeline (TNP), while 17 breaches were recorded in 2016 for the Trans Forcados Pipeline (TFP) with a capacity of 300,000 bpd. 
This article examines the nature of, and legal solutions to, the problem of oil pipeline insecurity in Nigeria. After discussing the importance of pipeline security to the Nigerian petroleum sector, it discusses challenges such as the high rate of pipeline vandalism, terrorism, sabotage, poor quality pipeline and inadequate legislation in securing the pipelines. To protect oil pipelines, which are critical national infrastructures, well thought out solutions to the problem of pipeline, vandalism and general insecurity of Nigerian oil pipelines must be addressed. The ultimate aim of this article is to examine how challenges inhibiting the safety of pipelines can be addressed. It reviews the existing laws and makes recommendations relating to pipeline security in Nigeria. Modern methods of dealing with pipeline security and the need for appropriate funding of the regulatory institutions saddled with the overall responsibility of managing the pipelines toensure their effectiveness is advocated for. There is also a needto overhaul the outdated legal framework on oil pipeline security to make them more focused and responsive.

This article is divided into five sections. After this introduction, section 2 examines the need for a holistic legal and institutional framework on oil pipeline security in Nigeria. Section 3 discusses the nature, scope and manifestations of pipeline insecurity in Nigeria. It appraises the legal barriers and gaps to promoting oil pipeline security in Nigeria. Section 4 discusses law and governance approaches to improving pipeline security in Nigeria. The article concludes in section 5 .

\section{THE NIGERIAN PETROLEUM INDUSTRY AND THE NEED FOR PIPELINE SECURITY}

The birth of the petroleum industry in Nigeria followed the discovery of crude oil in commercial quantity in Oloibiri in 1956. ${ }^{7}$ Since then, the Nigeria economy has been more or less dependent on petroleum. ${ }^{8}$ To facilitate the distribution of crude oil from the oil-rich Nigeria Delta to other parts of the country, a network of oil pipelines was constructed

7 For a discussion of the history of oil and gas production in Nigeria, see Damilola Olawuyi, Principles of Nigerian Environmental Law (Afe Babalola University Press, 2015) 2-25.

8 Ibid. 
to inter-link some states at strategic locations. ${ }^{9}$ Nigeria has a total pipeline grid of 5001 kilometres. ${ }^{10}$ This consists of 4315 kilometres of multiproduct pipelines and 666 kilometres of crude oil pipelines. ${ }^{11}$ These pipelines cut across the country, forming a network that links the 22 petroleum storage depots; the four refineries at, Port-Harcourt (I and II), Kaduna, and Warri; the off-shore terminals at Bonny and Escravos; and the jetties at Atlas Cove, Calabar, Okirika and Warri. ${ }^{12}$ This system of oil pipelines is used to transport crude oil to the refineries, covering a total distance of 719 kilometres. ${ }^{13}$ The multi-product pipelines transport products from the refineries/import receiving jetties to the 22 petroleum storage depots located in various parts of the country. The storage infrastructure consisting of 22 loading depots linked by pipeline of various diameters has aggregate installed capacities of 1,266,890 (PMS), 676,400 (DPK), 1,007,900 (AGO), and 74,000 (ATK) cubicmetre tonnes. ${ }^{14}$

Pipeline insecurity is driven mainly by themalicious or intentional destruction of pipelines, platforms, loading bays and other facilities for selfish purpose. Meanwhile, oil theft is the illegal taking away of oil by whatever means and diverting for personal benefit. The hacking into pipelines to steal crude oil to refine later and sell abroad is illegal bunkering. Pipeline vandalism is the intentional destruction of pipelines, platforms loading barge and other facilities for selfish interest. It is an illicit trade that involves the theft of crude oil and its derivative products through a variety of mechanisms. ${ }^{15}$ Asuni ${ }^{16}$ refers to illegal bunkering as oil taken from pipelines or flow stations, as well as extra crude oil added to legitimate cargo that is not accounted for.

9. A. Okoli and S. Orinya, "Oil Pipeline Vandalism and Nigeria's National Security" (2013) 13 GJHSSF 67.

10 Ibid.

11 ibid.

12 Ibid.

13 Ibid.

14 Federal Ministry of Information \& National Orientation, Report of the Special Committee on the Review of Petroleum Products Supply Distribution (2000) 10.

15 E. Adishi and M.O. Hunga, "Oil Theft, Illegal Bunkering and Pipeline Vandalism: It's Impact on Nigeria Economy" (2017), IIARD IJEBM 3 (2) 47.

16 J.B. Asuni. "Blood Oil in the Niger Delta" (Special Report, United States Institute of Peace 2009). <https://www.usip.org/sites/default/files/blood_oil_ nigerdelta_0.pdf $>$ accessed 22 August 2017. 
Nigeria is largely dependent on crude oil ${ }^{17}$ as its main source of foreign exchange. This makes crude oil and its derivatives paramount for the continued existence of the nation. Unfortunately, a lot of this resource is wasted and lost to vandals, criminals and oil thieves in huge sums, daily. ${ }^{18}$ The rate of vandalism in the Niger Delta region is on the increase,putting at stake Nigeria's economic mainstay. Currently, over 800,000 barrels of crude oil per day is lost to pipeline vandalism, oil bunkering and so on due to the general climate of insecurity around the oil pipelines. Nigeria's oil production, as projected in the 2016 budget targeted 2.2 million barrels per day, but now the target is 1.4 million barrels per day. ${ }^{19}$

Efforts made by the federal government to improve the security of the pipelines include hiring private security firms, equipping men and officers of the Nigerian armed forces to protect government facilities. These, however, has not put an end to the high rate of pipeline destruction and other oil facilities. In fact, criminal cartels with international connections have been formed. ${ }^{20}$ One outcome of this is that the significant investment devoted to pipeline security remains unaccountable for and the method of security is deemed ineffective. For instance, statistics show that Nigeria is losing as much as 400,000 barrels of oil per day. ${ }^{21}$

This common trend of illegal bunkering in Nigeria is overwhelming. It is not only limited to unauthorized bunkering and loading of ships but includes theft, diversion and smuggling of oil. Illegal bunkering is the most common form of oil theft, and it involves direct tapping of oil through pipeline puncture or rupture. ${ }^{22}$ It has now become a source of livelihood for some who regularly rupture pipelines and use the stolen crude oil for shipping business without required approvals, permits, licenses or valid documents, or in violation of the federal government

17 Lubepoint, "Curtailing Oil Theft, Illegal Bunkering via Legislation" (August 21, 2013). <https://lubepoint.wordpress.com/2013/08/21/4090/> accessed 8 September 2017.

18 E. Adishi and M. O. Hunga (n 15).

19 Vanguard, "Crude Oil: Nigeria Loses 800, 000 Barrels Daily to Pipeline VandalismKachikwu" The Vanguard (16 May 2016) <www.vanguardngr.com/2016/05/ crude-oil-nigeria-loses-800000-barrels-daily-to-pipeline-vandalism-kachikwu> accessed 25 August 2017.

20 E.Adishi and M. O.Hunga (n15) .

21 Lubepoint (n 17).

22 A. Okoli \& S.Orinya (n 9). 
guidelines. These are the issues this article seeks to address by proffering solutions that could help to secure the pipelines by paying more attention to the legal framework.

Against the above background, this article advocates the need for a comprehensive legal and institutional framework onpipelines security in Nigeria. It emphasizes the need for an agency of the government to manage the security of oil pipelines and coordinate activities of relevant security agencies as regards securing oil pipelines. A solid legal framework also enhances efficiency in the oil sector and improves the inflow of foreign direct investment into the oil industry.

\section{CAUSES AND MANIFESTATIONS OF OIL PIPELINE INSECURITY IN NIGERIA}

The Nigerian petroleum industry with the pipeline system currently in place faces challenges specifically on the prevalence of militancy and oil pipeline vandalism in the Niger Delta. While the former has significantly attenuated in the aftermath of the amnesty deal of $2009,{ }^{23}$ the latter appears to have escalated both in incidence and impact. According to Ogbeni, ${ }^{24}$ 16,083 pipeline breaks were recorded within the last 10 years adding that while 398 pipeline breaks representing 2.4 percent were due to ruptures, the activities of unpatriotic vandals accounted for 15,685 (about 97.5 percent) of those cases. ${ }^{25}$ We now focus attention on some notable challenges in order to unpack the scope and manifestations of oil pipeline insecurity in Nigeria.

\subsection{Vandalism of Oil Pipelines}

Vandalism affects adversely the oil companies, government, and even the environment. Vandalism is an action involving deliberate destruction of public or private property. ${ }^{26}$ According to the 2013 Annual Report of the Nigerian Extractive Industry Transparency Initiative (NEITI), Nigeria lost US $\$ 10.9$ billion to oil theft between 2009 and $2011 .{ }^{27}$ In the 1990 s,

23 A. Okoli, "The Political Ecology of the Niger Delta Crisis and the Prospects Lasting Peace in the Post-Amnesty Period" (2013) 13 GJHSSPS 37.

24 A. Okoli and S.Orinya (n 9).

25 Ibid.

26 A. Okoli and S.Orinya (n 9).

27 N. Onoja, "Nigeria loses \$11bn to oil theft, vandalism-NEITI"The Vanguard (30 July 2013). <http://www.vanguardngr.com/2013/07/nigeria-loses-11bn-tooil-theft-vandalism-neiti/>accessed 13 September 2017. 
vandals, mainly unemployed youths operating in remote areas and communities through which oil pipeline pass, punctured the pipes or took advantage of ruptured or leaking pipes to syphon fuel or other petroleum products into drums, plastic containers or storage cans for sale on the black market.

The technology employed was quite rudimentary, involving the use of funnels, drilling tools and plastic hoses to syphon the products. Also, only a few cases of vandalism occurred. For instance, in 1995, there were only seven reported cases of vandalism, and in the next three years 33, 34, and 57 cases were recorded. ${ }^{28}$ Towards the end of the military rule in Nigeria, the vandalism of oil pipelines, especially the pipelines for premium motor spirit (PMS), came into the limelight. In recent times, pipeline vandalism has assumed an alarming rate mainlybecause of the increase in the frequency of attacks on these pipelines and the increased sophistication of the technology used. ${ }^{29}$

\subsection{Pipeline Ruptures}

This is another important challenge that affects the security of oil pipelines. It is a major contributor to oil spill incidents. Corrosion of pipes and tanks involves the rupturing or leaking of production infrastructure that is "very old and lack regular inspection and maintenance". ${ }^{30}$ Corrosion plays a major role in oil spills because of the small size of the oilfields in the Niger Delta. Moreover, there is an extensive network of pipelines between the fields as well as numerous small networks of flow lines allowing many opportunities for leaks. ${ }^{31}$ In onshore areas, most pipelines and flow lines are laid above the ground. ${ }^{32}$ Pipelines, which have an estimatedlife span of about 15 years, are old and susceptible to corrosion.

\subsection{Pipeline Damages and Sabotage}

Deliberate sabotaging and the damage of pipelines are compromises to the security of oil pipelines. Pipelines also are sources of spills, leaks, and fires. Some pipelines are used beyond their life span. ${ }^{33}$

28 Federal Ministry of Information \& National Orientation (n 14).

29 F. C. Onuoha, "Oil Pipeline Sabotage in Nigeria: Dimensions, Actors and Implications for National Security" (2008) 17 ASR 99.

30 Ibid.

31 Ibid.

32 Ibid.

33 An estimated 15 years life span. 
Environmental pollution caused by oil pipeline spills could result from human factors to material defects: pipe corrosion, ground erosion, tectonic movements on the bottom, and encountering ship anchors and bottom trawls. Indeed pipeline defects could be the source of small but gradual to long-term leakage or leakage that might lead to an abrupt explosion.

In Nigeria, interfering with oil pipelines and installations has assumed huge dimensions and a variety of forms. There are three major identifiable forms, namely, illegal oil bunkering, oil pipeline vandalism and scooping, and oil terrorism. Compared to oil bunkering and pipeline vandalism, oil terrorism ${ }^{34}$ is a new vocabulary introduced by security analysts and scholars to describe the deliberate attack on pipeline systems in Iraq and elsewhere in the world by militias, freedom fighters, and insurgents.

The penalty for the offence of sabotaging oil pipelines in Nigeria is a very serious one. Section 2 of the Petroleum Production and Distribution (Anti-Sabotage) Act Cap. P12 LFN 2004 provides that if a person is convicted, he is to be sentenced either to death or to a maximum term of 21 years imprisonment. The provision of this Act is stringent enough to constitute a deterrent to would-be economic saboteurs. It is doubtful, however, if this provision has ever been enforced.

\subsection{Illegal Oil Bunkering}

Nigeria's most profitable illegal private business in the petroleum industry is illegal oil bunkering. Bunkering is the process of filling a ship with oil (or coal). Illegal oil bunkering, therefore, is a euphemism for oil theft. ${ }^{35}$ It involves tapping crude oil straight from the pipelines. Illegal oil bunkering is a dangerous process that persists in the creeks of the Niger Delta where oil pipelines form a grid.

Stealing oil from pipelines in the creeks involves building a temporary enclosure around a small portion of the underwater pipe, pumping out water from the enclosure, drilling a hole into the steel casing of the pipe through which the crude passes, and fitting the hole

34 A. J. Alawode, and I. O. Ogunleye, "Maintenance, Security, and Environmental Implications of Pipeline Damage and Ruptures in the Niger Delta Region" (2011) 12 PJST 565.

35 Human Rights Watch,"Illegal Oil Bunkering"<https://www.hrw.org/reports/ 2003/nigeria1103/5.htm> accessed 13 September 2017. 
with a pipe and control valve. ${ }^{36}$ The creek water is then allowed to flow back and fill the enclosure so that the set-up is underwater and, therefore, hidden from oil company inspectors. ${ }^{37}$ When crude oil is being pumped through the pipelines, sometimes at a pressure of 600 pounds per square inch (psi), the thieves are able to fill up to a 1,000 metric tonne barge within hours. ${ }^{38}$ The barge is afterwards moved offshore to a shipused for transportation and the oil sold on the high seas. ${ }^{39}$ Illegal oil bunkering also involves tapping directly into pipelines at a site removed from oil company facilities and connecting the pipes to barges that are hidden in small creeks under the cover of mangrove forests. ${ }^{40}$ It is said that over 10 per cent of the oil exported from Nigeria every year is actually illegally bunkered. ${ }^{41}$ Oil bunkering is now an activity that does not necessarily require the assistance of oil company staff to operate the equipment at the wellheads or allow access. ${ }^{42}$

\subsection{Oil Terrorism}

Oil terrorism is the latest of the ills plaguing the Nigerian oil industry. It involves such acts as the blowing up of oil pipelines, installations and platforms with explosives; and the seizure of oil barges, oil wells, flow stations, support vessels, and other oil facilities in order to prevent the exploitation and/or distribution of crude oil or its refined products. ${ }^{43}$ The first act of oil terrorism can be traced to December 2005, when the Movement for the Emancipation of the Niger Delta (MEND) blew up Shell's Opobo Pipeline in Delta State. ${ }^{44}$

In September 2005, after the arrest of Alhaji Asari Dokubo, ${ }^{45}$ militant groups in the Delta region instructed all multinational oil companies to leave the region, as they were preparing for a war with the Nigerian government. Since then militants in the region, seeking to control a greater share of the nation's oil wealth, have adopted a terrorist strategy

36 FC Onuoha (n 29).

37 Ibid.

38 Ibid.

39 Ibid.

40 Ibid.

41 Ibid.

42 Ibid.

43 Ibid.

44 F. C. Onuoha (n 29).

45 The leader of the Niger Delta Peoples Volunteer Force, who is widely regarded as a leader of the Ijaw nation. 
to impair the capacity of the petroleum industry to export crude oil. By doing so, they hoped that the federal government would lose the substantial revenue needed to sustain the machinery of government, and so be forced to meet their political, economic, and environmental demands of their people. ${ }^{46}$

\subsection{Inadequate Legal Framework on Oil Pipeline Security and Weak Enforcement}

Another key problem in this critical sector of the economy is the lack of diligent enforcement of extant laws that speak to the problem of pipeline destruction and sabotage. For example, Section 1 of the Petroleum Products and Distribution (Anti-Sabotage) Act of 1975 outlaws sabotage, i.e. the willful act of destroying, damaging, or obstructing petroleum installations and transportation infrastructure, thereby hindering petroleum production and distribution processes. ${ }^{47}$ This Act makes the willful obstruction or prevention of petroleum production and distribution an offence in Nigeria. ${ }^{48}$

The Act criminalizes all acts that disrupt petroleum production and distribution such as pipe vandalism, blow-ups, obstruction of petroleum production or distribution; obstruction of the procurement of petroleum products; or the obstruction of vehicles distributing petroleum products such as motor spirits, gas oil, diesel oil, automotive gas oil, fuel oil,aviation fuel, kerosene, liquefied petroleum gases and any lubricating oil or greases or other lubricant. Under this Act, the offence of sabotage is punishable by a death penalty or aterm of imprisonment not exceeding 21 years. ${ }^{49}$ This Act seeks to punish the principal offender, as well as anyone who aids, incites, counsels or procures any other person, to commit an act of sabotage, whether or not that other person actually does the act in question or not. Although the blow-up and vandalization of petroleum distribution pipelines, a principal cause of oil spillage in the Niger Delta, has been outlawed by this Act, onlya few arrests and prosecutions have ever been carried out under this law. Lack of committed enforcement of this anti-sabotage

46 F. C. Onuoha (n 29).

47 Petroleum Products and Distribution (Anti-Sabotage) Act of 1975, Laws of the Federation of Nigeria 2004, p. 12.

48 ss 1-2 ibid.

49 ibid. 
legislation has resulted in a culture of impunity in the Niger Delta region. To ensure oil pipeline security in Nigeria, all cases of pipeline sabotage must be thoroughly investigated, while full criminal penalties prescribed by the law must be applied in all proven cases.

Another problem is that there is no single comprehensive, specific law dealing with oil pipeline security in Nigeria. An examination of Nigerian legal framework on pipelines laws reveals that they only have provisions that relate to the general management of oil pipelines and those provisions that give limited roles to organizations such as the Nigeria Security and Civil Defence Corps (NSCDC) to secure oil pipelines. Although relevant laws exist that relate to the general management of oil pipelines, none of them comprehensively addresses the key causes of, and provide solutions to, the problem of pipeline insecurity in Nigeria. ${ }^{50}$

For instance, while sabotage is addressed in existing laws, none of the laws addresses other causes of pipeline insecurity such as negligent construction, accidental ruptures, oil terrorism and illegal bunkering. Considering the critical roles that oil pipelines play in Nigeria's oildependent economy, and in the oil and gas industry, there should be a separate law that deals solely with the all-important issue of pipeline security in the country. There is a need for a focused and committed effort towards ensuring that issues relating to pipeline security are squarely and elaborately dealt with.

\section{PROMOTING PIPELINE SECURITY IN NIGERIA}

Given the strategic importance of pipelines in Nigeria and the potential threat to its security, certain urgent steps should be taken to address issues revolving around the security of pipelines. These are discussed in the subsequent sub-sections.

50 Examples are: Oil Pipelines Act Cap. O7 L.F.N. 2004 (Oil Pipelines Act); Petroleum Act Cap.P10 L.F.N. 2004; Nigerian National Petroleum Corporation Act Cap N123 LFN 2004 (the NNPC Act); Oil and Gas Pipelines Regulations S.I 1995; and the Guidelines and Procedure for the Construction, Operation and Maintenance of Oil and Gas Pipelines and their Ancillary Facilities. As regards, general security of oil pipelines, the relevant laws are the: Petroleum Production and Distribution (Anti-Sabotage) Act CAP. P12 L.F.N. 2004; Nigeria Security and Civil Defence Corps Act No. 2, 2003 and its amendment Act: Nigeria Security and Civil Defence Corps (Amendment) Act No. 6, 2007. 


\subsection{The Need for Legal Provisions on Pipeline Integrity Methods}

The need toprovide for pipeline integrity methods in our laws will certainly help reduce cases of pipeline corrosion. Pipeline integrity methods include visual inspection, depth of cover survey, External NonDestructive Testing (NDT), cathodic protection monitoring, coating disbandment and damage survey, hydrostatic testing, geometry In-Line Inspection (ILI) tools, and ultrasonic in-line inspection tools. ${ }^{51}$ The pipeline network must be rigorously tested to ensure that they meet safety guidelines. When detected, these defects can be repaired.

These procedures help identify specific types of defects, such as, corrosion: the wastage or thinning of the pipe wall due to a chemical or electrochemical attack; gouging: the mechanical removal of metal from a local area on the surface of the pipe; metallurgical anomalies like hard spots, laminations, slivers, scabs and inclusions, and cracks due to fatigue stress corrosion and weld defects. Notably, hydrostatic testing is the predominant method for ascertaining the strength and reliability of a pipeline section that may be put into active service. ${ }^{52}$

\subsection{Need for Indigenous Companies to Operate Oil Pipelines}

Supporting indigenous oil companies to operate and manage oil pipelines could encourage effective participation of Nigerians, especially the local residents along the pipeline routes are located, in developing community surveillance initiatives to protect oil pipelines. When local communities invest in or operate pipelines in their communities, it gives them agreater sense of belonging, therefore motivating them to protect their investments from destruction. Endogenous ownership of pipelines could also lead to employment opportunities for local residents and in the long run reduce sabotage and other destructive activities.

To participate in oil pipeline development activities, indigenous companies can apply under the Oil Pipelines Act (OPA) ${ }^{53}$ to the Minister of Petroleum Resources who has the authority to grant "permits to survey routes for oil pipelines" and "licenses to construct, maintain and operate oil pipelines" 54 for their licences and permits. The OPA

51 A. J. Alawode and I. O. Ogunleye (n 34).

52 Ibid.

53 Oil Pipelines Act, Cap O7 L.F.N 2004.

54 ibid s 3. 
allows any person to make an application to the Minister for a permit to survey for oil pipelines. ${ }^{55}$ In fact, many highly profitable indigenous oil companies operate in different parts of the Niger Delta.

Nigeria enacted the Nigerian Oil and Gas Industry Content Development Act, 2010, which encourages the development of Nigerian content in the Nigerian oil and gas industry. ${ }^{56}$ The Act provides that:

Nigerian independent operators shall be given first consideration in the award of oil blocks, oil field licences, oil lifting licences and in all projects for which contract is to be awarded in the Nigerian oil and gas industry subject to the fulfilment of such conditions as may be specified by the Minister. ${ }^{57}$

This provision states that indigenous oil companies will be given first consideration where the award of contracts to maintain oil pipelines is carried out so far as they meet the specifications provided for by the minister of petroleum resources.

\subsection{Proper Funding and the need for Requisite Technology to Secure Oil Pipelines}

Relevant security agencies such as the Nigerian military, the police and the NSCDC need to be well-equipped tosecure the pipeline networks in Nigeria effectively. Proper funding of the security agencies motivates them to carry out their responsibilities efficiently. A major challenge that usually inhibits their effectiveness is corruption. Security agents can be easily bribed and made to compromise pipeline security. A good remuneration package could make them more effective in their surveillance work.

Moreover, the security agencies protecting critical infrastructure such as oil pipelines should also have the latest technology to protect the pipelines. Oil pipelines are long and cover great distances. Use of drone technology would be appropriate for the surveillance of these oil pipelines. We also cannot overstate the need for all security agencies to collaborate to rid the nation of oil theft. The government should givestrong encouragement to this. Finally, since Nigeria is not the only

55 ibid s 4 (1).

56 See generally the provisions of the Nigerian Oil and Gas Industry Content Development Act, 2010.

57 Nigerian Oil and Gas Industry Content Development Act, 2010, s 3(1). 
oil-producing country in the world, the government should learn best practices from the developed countries so as to overcome hindrances of this nature once and for all.

\subsection{Need for Regulation Covering Location or Citation of Pipelines}

Pipelines are usually vulnerable to vandalism, sabotage and terrorist attack with firearms, explosives and other physical means. ${ }^{58}$ Pipelines are also known to be vulnerable to cyber-attacks. ${ }^{59}$ In Colombia, for example, rebels havebombed the Caño Limón oil pipeline and other pipelines over 950 times since 1993. ${ }^{60}$ In 1996, the London police reportedly foiled a plot by the Irish Republican Army to bomb gas pipelines and other utilities across the city of London. ${ }^{61}$ Nigerian militants also attacked pipelines and related facilities, including the bombing of three oil pipelines in May 2007. ${ }^{62}$ Moreover, a Mexican rebel group reportedly detonated bombs along Mexican oil and natural gas pipelines in July and September $2007 .{ }^{63}$

Nigeria must take a cue from the advanced countries by ensuring that pipelines are not located inplaces of high population density where many lives could be lost in case of an explosion or some form of attack.

\subsection{Need for a Comprehensive Law on Oil Pipeline Security in Nigeria}

Existing laws on the security of oil pipelines cannot be left scattered in different statutes as is the case currently. There is an immediate need for an all-encompassing law to deal with this issue of security of oil pipelines squarely. This comprehensive law will have detailed provisions on oil pipeline security and provide for an agency to implement the provisions of this law religiously. The law should also harmonize the punishments for violating the security of pipelines as contained in

58 1PW Parfomak, "Pipeline Safety and Security: Federal Programs" (Congressional Research Service Reports,

59 February 2009) < http://digitalcommons.unl.edu/cgi/viewcontent.cgi?article $=1033 \&$ context $=$ crsdocs $>$ accessed 13 September 2017.

59 Ibid.

60 Ibid.

61 Ibid.

62 Ibid.

63 Ibid. 
several other laws in Nigeria. This calls for a reform of existing laws on oil pipelines security. Thelaw creating a new agency of government with sole responsibility for oil pipelines security in Nigeria should grant adequate power to do its job well. This agency must be well funded and equipped with the right technology to effectively monitor and secure the pipelines. The agency can utilize a multi-agency approach to coordinate activities of several relevant security agencies and other stakeholders (especially the oil companies) for operational efficiency.

\subsection{Need for a Structured "Multi-Agency Security Response Approach (MASRA)" to Oil Pipeline Security in Nigeria}

The Multi-Agency Security Response Approach (MASRA) simply implies the coming together of all relevant security agencies in a formal and organized manner to deal with all issues relating to oil pipelines security in Nigeria. This approach can be backed up by an Act of the Nigerian National Assembly or may result into an agency created by the federal government to deal with oil pipelines security issues. This was the approach that government used to deal with corruption when it created the Economic and Financial Crimes Commission (EFCC) and Independent Corrupt Practices Commission (ICPC). Top officers of these agencies were recruited from the police, customs and similar security formations in the country. This approach will ensure proper coordination of efforts and the sharing of intelligence to deal with every kind of sabotage of the oil infrastructure. Organizations such as the Nigerian Army, Nigerian Police; Nigeria Security and Civil Defence Corps and other relevant security organizations would be needed for this approach to be successful. We cannot overemphasize that these security agencies must be properly funded, and they must have requisite skills and technology at their disposal.

\section{CONCLUSION}

Oil is strategic to the Nigerian economy, and oil pipelines which are used for the transportation oil and gas resources must be safe, secure and well protected. Challenges relating to pipeline security in Nigeria, specifically those identified in this article, can be surmounted with strong determination by all the stakeholders. However, practical problems such as lack of political will; unemployment; poverty; 
corruption and general insecurity must also be dealt with head-on for oil pipeline insecurity to become a thing of the past. Issues surrounding security must not be taken lightly especially given the pivotal importance of the petroleum industry to the Nigerian economy and society. 